\title{
Retraction Note: Monitoring of mountain ecological environment based on Bayesian estimation and testing of motor memory function in mice
}

\author{
Yanqiu Liu' ${ }^{1}$ Yong Wang ${ }^{1}$
}

Published online: 3 November 2021

(c) Saudi Society for Geosciences 2021

Retraction Note: Arabian Journal of Geosciences (2021) 14: 1754

https://doi.org/10.1007/s12517-021-08080-5

The Editor-in-Chief and the Publisher have retracted this article because the content of this article is nonsensical. The peer review process was not carried out in accordance with the Publisher's peer review policy. The authors have not responded to correspondence regarding this retraction.

The original article can be found online at https://doi.org/10.1007/ s12517-021-08080-5.

Yong Wang

yanqiu8206@163.com

1 College of Physical Education, Sanming University,

Sanming 365004, Fujian, China 